\title{
Die juridiese problematiek van grondbesit in die boek Rut
}

\author{
Milda Stanton \& Pieter Venter \\ Departement Ou-Testamentiese Wetenskap \\ Universiteit van Pretoria
}

\begin{abstract}
The juridical problem of land ownership in the book of Ruth

Juridical matters play an important role in the book of Ruth. There appears to be a contradiction between Ruth 1:21 and Ruth 4:3. In the former, Naomi is depicted as a desperately poor ("empty") widow. In the latter, Naomi is unexpectedly presented as the owner of land. This contradiction can be solved by understanding Naomi's right in respect of her late husband's land as a right other than ownership. A study of female ownership of land, the right of a wife to inherit from her husband, analysis of the literary elements in the book of Ruth, the rural backdrop, the theme of survival and the vocabulary in the narrative, lead to the conclusion that we are here dealing with what would today be recognised as a usufruct.
\end{abstract}

\section{INLEIDING}

\subsection{Problematiek}

"Die juiste hantering van juridiese aangeleenthede in die boek Rut, vorm 'n belangrike tema in die boek. Dit dra by tot die spanning en word gebruik in die ontknoping van die plot en intrige" (Loader 1994a:22).

Juridiese aangeleenthede kom ter sprake in Rut 4:3 tot 5. Die problematiek in Rut 4:4, het meer aandag geniet in die literatuur as dié in verse 3 en 5. Rut 4:4 het vrae laat ontstaan oor die toepassing van die lossingsreg en die leviraatshuwelik in die tyd waarin die boek Rut afspeel. Rut 4:3 het vrae laat ontstaan rondom vroulike erfreg en grondbesit. Rut 4:5 hou in die oorspronklike teks vir Rut voor as mede-eienares van die grond wat Naomi wil verkoop. 
In Rut 1:21 word Naomi as 'n verarmde weduwee geteken en in Rut 4:3 onverwags $^{1}$ as die eienares van grond wat sy teen 'n vergoeding van die hand wil sit. Die Leitwort in Rut 1:21 ריקם (leeg) in teenstelling met מלה (vol). Naomi se krisis wat met die term leeg beskryf word, beteken dat sy terugkeer sonder enige hoop op 'n nageslag. Dit kan dus impliseer dat sy geen hoop op versorging het nie. Sy is gestroop van familie en van materiële lewensmiddele. ${ }^{2}$ Die aanduiding dat sy grond het om te verkoop in Rut 4:3, kom dus as 'n verrassing.

Die oënskynlike teenspraak tussen Rut 1:21 en Rut 4:3 kan moontlik opgeklaar word deur aan te toon dat dit wat Naomi gehad het om te verkoop, op 'n ander reg as eiendomsreg dui. Sy doen nie afstand in Rut 4:3 van haar eiendomsreg nie, maar van 'n ander soort reg wat haar uit hoofde van haar erfreg toegeval het.

Hierdie hipotese kan gestaaf word deur 'n ontleding van die tema van die verhaal, die agtergrond waarteen die verhaal afspeel en die taalgebruik in die boek.

\subsection{Werkwyse}

Die volgende aspekte word ondersoek:

- Die oorlewingsmotief in die boek Rut;

- Die antieke erfreg, met spesifieke verwysing na die vrou se status en regte;

- $\quad$ Die vrou se status in die antieke reg met spesifieke verwysing na haar reg om grond te besit;

- $\quad$ Die gewoontereg: die antieke beskouing daarvan (aan die hand van die voorbeelde in Rut 4:4) en ooreenkomste met hedendaagse gebruike;

- $\quad$ Sosio-kulturele aangeleenthede. Hierdie studie is noodsaaklik in die vraag na die moontlikheid om hedendaagse begrippe en regsterminologie van toepassing te maak op antieke gebruike en reëls;

- $\quad$ Die rol van die milieu en taalgebruik. Hierdie aspekte blyk hoogs funksioneel te wees in die bewys van die hipotese van hierdie studie.

\footnotetext{
1 "Dass Noömi ein Acker hat ... kommt höchst unerwartet, und macht den Rechtsfall besonders verwickelt..." (Gerleman 1965:9).

${ }^{2}$ Brueggeman (1977:32, voetnota 12), bevestig hierdie insig: "The theme of empty_becomes full, may be well linked to landless becoming landed." Jesaja 62:4 vergelyk ook die onvrugbare (verstote) vrou met "... 'n land wat verlate lê ...."
} 
Uit die voorgaande blyk dat hierdie nie net'n literêr-wetenskaplike ondersoek kan wees nie. Dit is veral ook 'n sosiaal-wetenskaplike ondersoek. Die twee benaderings moet dus vir doeleindes van hierdie studie hand aan hand gaan.

\subsection{Interpretasie van gapings in die narratief}

Alter (1981) maak gebruik van die tegniek van "reticence". Sy werkwyse kom handig te pas by die studie van 'n verhaal soos dié van Rut, aangesien die verhaal kripties geskryf is. Hierdie werkwyse stel ons in staat om die yl leidrade in die teks op te volg en die gapings in te vul wat Bybelse narratiewe dikwels laat. Met hierdie metode bly daar altyd ' $n$ element van verrassing wat ontplooi kan word (Alter 1981:127). Hierdie metode is hier gevolg om die tema van in die verhaal vas te stel. Vir 'n sosiaal wetenskaplike ondersoek soos hierdie, kan dit ook van die uiterste belang wees.

\subsection{Dekonstruksie}

Loader (1994a: 25-26), beskryf Naomi as “... die protagonis, en 'n mens wat die inisiatief neem om iets aan haar situasie te doen ...." Dit is 'n poging om Naomi te karakteriseer, waar die verhaal self geen karakterbeskrywings gee nie. Alter se werkwyse van "reticence", kan vrugbaar vir so 'n tipe karakterisering gebruik word. Loader (1994a:19) laat ook die gaping wat dit moontlik maak om 'n studie van hierdie aard aan te pak: "Dit is moontlik om die vertelling op 'n kreatiewe manier te lees ... vanuit 'n ander gesigspunt as die histories-waarskynlike ..."

In hierdie studie is gepoog om hierdie doel te bereik deur sekere verse opnuut te ontleed en krities na nuwe vertalings- en interpretasiemoontlikhede te kyk. Dit kan met die begrip "dekonstruksie" aangedui word. Die metode van "teruglees" is ook gevolg. Omdat die verhaal nie vir die eerste keer gelees word nie, is daar inligting oor die karakters bekend wat reeds by die begin van ' $n$ tweede of verdere lees ' $n$ rol speel. So word Naomi reeds aan die begin van ' $n$ verdere lees as planberamer gesien.

\section{DIE OORLEWINGSMOTIEF IN DIE BOEK RUT}

Oorlewing vorm 'n sentrale tema in die boek Rut. Die kreatiewe herlees van die verhaal maak dit duidelik. Toe Naomi die besluit geneem het om terug te keer na haar eie land, was oorlewing haar grootste enkele motivering. Die verhaal begin deur Naomi te beskryf as ' $n$ vrou gestroop van familie, en dus van oorlewing. Ter wille van oorlewing verlaat sy saam met haar gesin Betlehem. Wanneer die hongersnood in haar land verby is, besluit sy om daarheen terug te gaan. Dit is duidelik uit die karakterisering van Naomi in die verdere verloop van die verhaal, dat sy 'n vindingryke vrou was. Haar planne 
het nie gou opgeraak nie. Die manier waarop sy optree in die verdere verloop van die verhaal, maak dit onwaarskynlik dat sy planloos teruggekeer het. Die inligting in Rut 4:3 dat sy grond het om te verkoop, maak dit moontlik dat hierdie grond 'n rol kon speel in haar beplanning.

Die stuk grond wat haar man in Israel agtergelaat het, was moontlik nog in haar familie se besit. Sy kon nog 'n reg daarop hê. By haar terugkeer is haar plan waarskynlik reeds goed uitgewerk. Sy sal die persoon wat die grond onder sy beheer het, taktvol nader en hom daarop wys dat sy nou terug is. Sy sal hom ook wys op sy plig om haar onder sy beskerming te neem. (Hierdie plan het wel in Rut 4:4 gerealiseer, hoewel in gewysigde vorm.)

Dit kan wees dat haar man, Elimeleg, die beheer van sy grond aan iemand toegewys het vir die duur van sy afwesigheid. Hierdie persoon kon moontlik hulle familielid Boas wees. Uit Rut 2:20, is dit duidelik dat sy presies geweet het wie Boas is. Sy weet ook presies waar die grond is. Sy het immers self daar gewoon. Toe sy Rut by haar planne betrek het, het sy haar juis in daardie rigting gestuur om te gaan are optel. Die haglike situasie waarin sy haar bevind, word oneindig vererger deur die toevoeging van Rut, ofskoon sy lojaal en nederig deur die skrywer voorgehou, word. ${ }^{3}$ Dit moes vir Naomi 'n nuwe bekommernis meegebring het. Skielik is daar nou twee monde om te voed! Dit sou nie meer moontlik wees om haar oorspronklike plan te volg nie.

Sy kan ook nie op God reken nie. God (שדי) het haar in die steek gelaat (Rut 1:20). Hy is in hierdie konteks sowel die Gewer van goeie gawes as die Een wat rampe oor 'n mens kan bring (vgl in die verband ook Jes 3:6, Joël 1:15 ). Sy sal dus haar planne moet verander. Sy probeer tevergeefs van Rut ontslae raak. Die moontlikheid dat die "huil"-handeling in Rut 1:9-14 ook deel kon wees van 'n antieke ritueel, is nie uitgesluit nie. "... hul stemme verhef..." (Rut 1:9 en 14, [1933 Afrikaanse vertaling]), skep die indruk van 'n geforseerde huil. Orpa en Rut (wat self ook sonder mans en kinders gelaat is), is moontlik self desperaat vir oorlewing.

Toe Rut vervolgens weier om Naomi se sy te verlaat, moet sy Rut teen wil en dank by haar planne insluit. In plaas daarvan om, soos sy oorspronklik beplan het, self die familielid te nader wat in beheer is van haar man se grond, sou sy nou vir Rut daarheen stuur. Daarvoor wend sy haar tot die aanvaarde gebruik van "are optel". Dit was 'n voorreg wat net die armste van armes toegekom het (vgl Deut 24:19 en Lev 23:22). Levitikus 19:9 en 10 sluit

\footnotetext{
${ }^{3}$ Gunkel, aangehaal deur Loader (1994a:14), meen hierdie is bloot 'n "mooi verhaal van menslike trou .... ." Hy wys egter ook op die honger-migrasie-motief wat hom hier herhaal (vgl Loader 1994a:25). Prinsloo (1992:43-44), beklemtoon telkens Rut se nederigheid. Die woorde "... die een in wie se oë ek guns mag vind ..." kom drie maal in hoofstuk 2 voor en word beskou as 'n antieke idioom om ondergeskiktheid te beklemtoon. Myns insiens weet die leser tog reeds dat die twee vroue besig is om listige planne te smee.
} 
vreemdelinge by hierdie voorreg in. Die indruk word wel geskep dat Rut eers guns moes vind in Boas se oë alvorens sy vrylik kon are optel, al maak die wet daarvoor voorsiening. Wat verder opval, is dat die gemeenskap nie die vroue te hulp kom nie. As Naomi vroeër die vrou van 'n (gesiene?) grondeienaar in die omgewing was, moes sy bekend gewees het, soos blyk uit Rut 1:18. Haar terugkeer het trouens 'n opskudding veroorsaak, omdat almal haar herken het. Kan die gemeenskap se huiwering wees as gevolg van Rut se teenwoordigheid? Die feit dat sy 'n Moabiet was, word telkens beklemtoon (Rut 1:20-22; 2:1, 2, 6, 21; 4:5, 10).

'n Ander moontlikheid is dat Elimeleg se vertrek uit Betlehem as "sondig" en dus onaanvaarbar beskou is, Haar terugkeer is dus met afkeer bejeën. ${ }^{4}$ Omdat God self sy volk van grond voorsien het (vgl Deut 26:8 en Lev $25: 23,28)$, kon 'n emigrasie uit Israel ook meebring dat die verbond met God verder verbreek is deurdat jy jou in die vreemde land skuldig kon maak aan afgodediens of die aanvaarding van die bestaan van ander gode naas $\mathrm{JHWH}$. Die reël of gebruik dat vroue nie van hul mans kon erf nie, het moontlik ook sy ontstaan hieraan te danke. Die mans was ongehoorsaam, en het met vreemde vroue getrou. Sou hy te sterwe kom en sy erf die grond en trou vervolgens met 'n afgodedienaar, sou dit neerkom op die vervreemding van grond wat aan $\mathrm{JHWH}^{\text {behoort. }}{ }^{5}$

Benewens die "reg" wat armes gehad het om are en olywe op te tel, is daar min voorskrifte oor die plig van die gemeenskap om aktief in te gryp in die ellende van die arm weduwee. Deutoronomium 26:12 maak dit egter duidelik dat sy nie geïgnoreer kon word nie. In die boek Rut lyk dit of die gemeenskap net hul skouers opgetrek het en verder passief gebly het. Daarom moes Naomi self inisiatief neem. Die losser, daarenteen, het gewoonlik goed geweet wanneer hy die plig gehad het om grond te koop (vgl Rut 3:12, Jer 32:6-15).

Dit volg vanselfsprekend dat as daar hoegenaamd van so 'n plig op die gemeenskap sprake was, dit in 'n baie mindere mate, of glad nie, op die vreemdeling-weduwee van toepassing sou wees nie. In hierdie verband is Boas se opmerking teenoor Rut in Rut 3:11 opvallend. Teen hierdie tyd het Rut so 'n goeie reputasie opgebou, dat die hele gemeenskap dit aanprys (“... want al die mense weet dat jy 'n goeie vrou is ..."). Nogtans het niemand 'n helpende hand uitgesteek nie. Naomi moes 'n ekstreme optrede op Rut afdwing voordat Boas tot insigte sou kom (Rut 3:6 ev).

\footnotetext{
${ }^{4}$ Sien ook Loader (1994a:13) wat die lot van Elimeleg en sy seuns aan die hand van 'n vers uit die Targum, beskryf as 'n straf vir die oortreding van voorskrifte uit die Torah.

${ }^{5}$ Sien Eskenazi (1992:35): "The fear of mixed marriages with their concomitant loss of property to the community, makes most sense when women can, in fact, inherit."
} 
As die gebruik verder was dat 'n persoon op enige stuk land kon gaan are optel, is dit onwaarskynlik dat sy "toevallig" by Boas, die "vermoënde familielid" (Rut 2:1), sou beland. Rut gee voor dat sy gaan are optel op hierdie stuk land in die hoop dat "iemand" aan haar guns sal betoon. Dit is meer waarskynlik dat Naomi reeds aan haar uitgewys het watter stuk land Boas s'n is, en haar in daardie rigting gelei het om seker te maak Boas sien haar raak.

Die Boek Rut is 'n voorbeeld van hoedat 'n arm weduwee pro-aktief moes optree ten einde te oorleef. Dit maak dit die moontlikheid dat sy grond kon besit baie onwaarskynlik en die moontlikheid dat daar 'n ander erfregtelike meganisme vir haar oorlewing kon bestaan het, al hoe groter.

\section{VROUE ERFREG IN DIE OU TESTAMENT}

Die primêre vraag waarom dit hier gaan, is of Naomi die eienares van grond was wat sy kon verkoop. Ten einde Naomi se regsposisie in dié verband te bepaal, is dit in die eerste plek nodig om vas te stel of vroue van hul mans kon erf, want Deuteronomium 21:15 bevat die uitdruklike bepaling dat 'n man se eersgebore seun sy erfgenaam is. Hierdeur word die eggenote oënskynlik uitgesluit van enige vorm van erfreg van haar man. (In die NAV is הנחילו, "sy erflating", in Deuteronomium 21:16, verkeerdelik met "in sy testament" vertaal. 'n Testament vervang die aanvaarde reëls van erfopvolging, en is dus juis hier heeltemal onvanpas. Dit is ook onseker of die verskynsel van 'n testament, skriftelik of mondeling, in hierdie tyd al bekend was).

Hierdie stelling behoort as grond daarvoor te dien dat Naomi nie die eienares van Elimeleg se grond kon wees nie. De Vaux (1962:106) beklemtoon hierdie opvatting, maar gaan teen die verwagting in, voort om te sê dat ons 'n voorbeeld hiervan (waarvan?) in die boek Rut vind: "Naomi heeft een bezit die zij uit armoede moeten verkopen." De Vaux bied geen beter verklaring as dat sy opgetree het as "behoeder" van haar twee oorlede seuns se regte nie. Dit is duidelik dat de Vaux "eiendomsreg" in gedagte het as hy die term "besit" gebruik. Die begrippe "eiendomsreg" en "besit" word egter vandag nog verwar en verkeerd aangewend (vgl Van den Brink1995:144145). 'n Eienaar "besit" nie altyd sy grond nie. Dit kan in die hande van 'n huurder wees. Vir doeleindes van hierdie artikel is dit ongelukkig nie moontlik om hierdie twee regsterme volledig te bespreek nie.

Wat die vraag betref of dogters wel van hul vaders kon erf, het ons die volgende voorbeelde in die Bybel: 
- Numeri 27:1-11 en Josua 17:3-6: Selofgad se dogters. Die bestaande posisie word hersien en omgekeer deur Moses se bekwame regspraak. Die oudste dogter kan erf as die man geen seuns gehad het nie. ${ }^{6}$ In Num 36:6-9 word die beginsel dat dogters kon erf, uitgebrei. Die beginsel van "aanwas" kom vir die eerste keer ter sprake. Dit is die geval waar ' $n$ vooroorlede broer of suster se erfporsie gelykop verdeel word tussen dié van die oorblywende broers en susters.

- Job 32:13-14: Job het sy dogters saam met hulle broers laat erf. As hierdie insident dui op 'n tydperk toe die maak van 'n testament of die uiting van 'n laaste wilsbesluit reeds gebruiklik was, sou die bestaande intestate erfregreëls langs hierdie weg gewysig kon word. Of skrif 'n voorvereiste daarvoor was, kan moeilik vasgestel word. Daar word insgelyks geen melding gemaak van die moontlikheid dat Job se vrou ook geërf het nie.

'n Baie interessante geval waardeur vererwing binne familieverband verseker is, is opgeteken in 1 Kronieke 2:34. Sesan, uit die stam van Juda, het sy slaaf met sy dogter laat trou ten einde haar in staat te stel om sy geslag te laat voortbestaan. Dit is 'n soort omgekeerde Bilha- (Gen 30:3-4), Silpa- (Gen 30:9-10) en Hagar- (Gen 16:2-4) geval. Die Rut-verhaal bevat die enigste voorbeeld waar ' $n$ vrou, as beweerde eienares van grond, haar skoondogter met haar naasbestaande familielid laat trou ten einde die grond in die familie te laat bly.

\section{DIE VROU AS EIENARES VAN GROND IN DIE OU TESTAMENT}

Deur aan te toon dat dogters wel van hul vaders kon erf, word bewys dat 'n vroulike persoon wel die eienares van grond kon wees. Die voorbeeld uit 2 Konings 8 word gewoonlik gebruik om aan te toon dat 'n vrou die eienares van grond kon wees. Myns insiens is dit foutief. By die herlees van 2 Konings 8:6, word dit duidelik dat daar nie na die grond as deel van die vrou se eiendom verwys word nie. Die koning beveel wel dat sy "alles wat aan haar behoort" moet terugkry, sowel as die opbrengs van die grond. Die grond self word egter nie vermeld nie. Haar man, is waarskynlik tydens hulle verblyf in die land van die Filistyne oorlede is (onthou dat 2 Kon 4:14 klem lê daarop dat haar man reeds oud was). In 1 Konings 17:1-26 word moontlik van dieselfde

\footnotetext{
${ }^{6}$ Volgens Patrick (1986:184), kon "intrinsic right" uiteindelik geskied deurdat Moses JHWH in hierdie verband geraadpleeg het. Hierdie is myns insiens 'n moderne perspektief, wat nie in die antieke erfreg ingelees kan word nie.
} 
vrou vertel. Hier word sy voorgehou as die "eienares" van die huis. Daar moet egter in gedagte gehou word dat בעל 'n sekondêre betekenis het, naamlik "heer" of "baas", en nie net "eienaar" hoef te beteken nie.

Die vertelling uit 2 Konings 8 asook die een in 2 Samuel 14:4-11 (ofskoon die gebeure 'n blote opvoering was) staaf egter 'n paar ander beginsels: die oudste seun word as die erfgenaam beskou, die grond moet in die familie bly en die vrou erf nie van haar man nie. Albei vertellings wil dus beklemtoon dat as die laaste erfgenaam vergaan, vergaan die weduwee ook. Hieruit kan moontlik afgelei word dat moeders ook nie van hul kinders kon erf nie, hoewel hierdie diskwalifikasie nêrens in die Ou Testament uitgespel word nie.

Die kroon op die weerlegging van die alom aanvaarde uitgangspunt dat vroue nie grond kon besit nie, is die uitspraak in Spreuke 31: 16, dat die ideale vrou inderwaarheid behoort na te dink oor 'n stuk grond, en dit dan sal koop indien sy as voortreflik beskou wil word! Op grond hiervan kan dus moontlik geredeneer word dat Naomi die die grond wat sy te koop aanbied, op 'n ander wyse as deur vererwing kon verkry het. Rut 4:3 diskwalifiseer egter uitdruklik hierdie moontlikheid, deurdat daarna verwys word as Elimeleg se grond.

Loader (1994a:12), beskou die gedeelte uit Numeri 27 as teenstrydig met die posisie wat voorgegee word in 2 Konings 8 en Rut 4. Eersgenoemde gedeelte bevestig volgens hom dat vroue nie grond kon erf nie terwyl laasgenoemde twee voorbeelde onvoorwaardelike grondbesit deur vroue veronderstel. Hy verklaar die "teenstrydigheid" deur aan die hand te doen dat die opvatting dat vroue nie grond kon besit nie, uit 'n later era dateer. Hier word "grondeienaarskap" duidelik verwar met "erf van grond". Hierdie verwarring is algemeen, en het myns insiens gelei tot die foutiewe opvatting dat vroue nie grond kon besit het nie. Die teenspraak tussen Rut 1:21 en Rut $4: 3$ is nie in die onderskeie tydsgewrigte geleë nie, maar in die teks self.

Uit die voorgaande kan gepostuleer word dat vroue wel eienares van grond kon wees, maar dat Naomi dit nie kon gewees het nie, omdat sy nie van haar man geërf het nie. Dit sal dus nodig wees om 'n ander moontlike reg ten aansien van haar man se grond, wat haar kon toegeval het, te ondersoek. In hierdie opsig speel die gewoontereg, wat as kunstige skryftegniek in Rut 4:4 figureer, 'n belangrike rol.

\section{DIE ROL VAN DIE GEWOONTEREG IN DIE OU TESTAMENT}

Daaglikse behoeftes lei tot regsreëls wat sosiale afdwingbaar is. So het die term "gewoontereg" sy inslag gevind. Die uitdrukking "In die dae toe die 
Rigters regeer het" (Rut 1:1), dui volgens Loader (1994a:22) op 'n tydperk toe daar reg gespreek is volgens die gewoontereg. De Vaux (1962:258) noem dat die Hetitiese geskrewe reg so ver terug gaan as die $13 \mathrm{e}$ eeu vC. Dit is egter dikwels nie tot die letter toe gevolg nie: "Zij hebben bij voorkeur zeer bezondere gevallen op het oog, omdat men veronderstelde dat de normale zaken door eenvoudige en algemeen aangenome regels werden opgelost". Vuilleumier (1988:197), skryf na aanleiding van die Leviraatshuwelik:

\begin{abstract}
Nun hat das Deuteronomium einen Brauch legalisiert, der schon lange vorher geübt wurde: l'usage fait loi ... aber es fällt auf, dass die landwirtschäftliche Atmosphäre, wie sie im Buche Ruth geschildert wird, näher bei den alten bäuerlichen Gebrauchen steht als bei der Latifundiengewirschaft.
\end{abstract}

Met hierdie stelling bring hy die sake waarom dit hier gaan, netjies bymekaar. Nie alleen kom dit daarop neer dat die landelike agtergrond 'n bepaalde atmosfeer wil skep nie, maar ook dat die wyse waarop die gebruike wat gegeld het aangebied word, bydra tot hierdie atmosfeer. Die aanwending van sekere landelik simbole in die vertelling (soos aangetoon sal word), dra op sy beurt by tot die voorbereiding van 'n speelveld en 'n atmosfeer waarbinne sekere gebruike moes gegeld het.

Die twee belangrikste gebruike waarom dit hier gaan, is die aanwending van die lossingsreg (Lev 25:25) en die leviraatshuwelik (Deut 25:5-10, Gen 38). Die lossingsreg is daarop gemik om 'n verarmde familielid te help, terwyl die plig uit hoofde van die leviraatshuwelik van toepassing is op die broer van die oorledene. Die losser hoef nie noodwendig ' $n$ swaer te wees nie, maar 'n naby familielid.

Daar is verskeie verklarings waarom die skrywer die twee prosedures in Rut 4:4 met mekaar laat vervloei. Een daarvan is dat dit 'n vernuftige skryftegniek is wat ' $n$ belangrike sleutelrol speel in die ontknoping van die verhaal. Hiermee word op kunstige wyse, aan die hand van twee simboliese tekenhandelinge, verteenwoordiging gebied aan die twee belangrike temas waarom dit in die boek Rut gaan: oorlewing en die voortbestaan van 'n nageslag.

' $n$ Ander verklaring is dat die skrywer reeds ver in tyd verwyder was van hierdie gebruike en nie meer die besonderhede geken het nie. Daarby vind hy dit nodig om die prosedure aan sy lesers te verduidelik, asof hulle ook nie meer op hoogte daarvan sou wees nie. 'n Belangrike deel van die leviraatshuwelik wat in Deuteronomium 25:9 beskryf word ten aansien van die sandaalprosedure, word hier weggelaat. Dit is die gedeelte waar die weduwee 
haar swaer wat haar weier, in die gesig moet spoeg. Die belang hiervan is dat aangetoon kan word dat gevestigde gewoontereg ook in onbruik kan verval. ${ }^{7}$ Gewoonte kan dus nie net gemenereg skep nie, maar dit ook afskaf. Wat wel behoue gebly het, is dat die regsprosedure by die koop van grond gevestig is deur die sandaal-prosedure, en dat hierdie gevestigde regshandeling ook op die gewoonteregsreël van die lossing van toepassing gemaak is. Die prosedure speel hom af in die stadspoort, tradisioneel die plek waar regspleging plaasgevind het, en beslissing sowel as voltrekking gemaak is. ${ }^{8}$

Die derde gebruik waarom dit hier gaan, is minder sigbaar. Dit word in Rut 4:3 gesuggereer. Vanweë die vinnige pas van die vertelling, waarin die gebeure blitsvinnig opmekaar volg en wat strook met Boas se oorgretigheid om vir Rut te verwerf, is dit misgekyk. Daar moes 'n ander reg (na aanleiding van 'n gebruik) vir Naomi gevestig gewees het wat haar 'n quasi-eienares van grond laat lyk. Dit moes 'n reg wees wat deur die landelike leefwyse oor 'n baie lang tydperk gevestig is, ten einde vir die weduwee (wat nie van haar man kon erf nie) te voorsien.

Vanweë opvallende ooreenkomste met 'n regsverskynsel wat ons vandag ken as "vruggebruik", verg hierdie moontlike reg ten aansien van grond, wat in Rut 4:3 figureer, verdere ondersoek.

\section{6. 'N MOONTLIKE ANDER REG VIR NAOMI}

Die ooreenkomste wat Naomi se reg in Rut 4:3 vertoon met dié van 'n vruggebruik, is die volgende:

- $\quad$ Dit moet 'n reg wees wat teen vergoeding van die hand gesit kan word.

- $\quad$ Dit moet 'n reg wees wat sy kon uitgehou het toe haar man gesterf het, ten spyte van die feit dat haar seuns (teoreties opeenvolgend) of in hierdie geval moontlik iemand anders, die grond kon geërf het.

- $\quad$ Dit moet 'n reg wees waarvoor besit nie 'n voorvereiste is nie.

\footnotetext{
${ }^{7}$ In die Suid Afrikaanse reg is die toonaangewende beslissing in die verband Green vs Fitzgerald (1914 AD 88), waarin beslis is dat die reël van die ou Romeins Hollandse Reg dat owerspel 'n misdaad is, deur onbruik verval het.

${ }^{8}$ Vergelyk De Vaux 1962:272. Wat opval is dat die vroue nie teenwoordig is nie. Dit laat vrae ontstaan rondom die gesag waarmee Boas namens Naomi kon optree. Het die verskynsel van "volmag" soos ons dit vandag ken al bestaan? Voorbeelde hiervan kom nie in die Ou Testament voor nie, tensy aanvaar kan word dat die bruidegom by die leviraatshuwelik, as 'n soort gevolmagtigde vir sy oorlede broer opgetree het.
} 
- $\quad$ Dit moet 'n reg wees wat as oogmerk het die oorlewing van die weduwee, sowel as om die grond in die familie te hou. Soos aangedui, vorm hierdie die sentrale tema in die boek Rut.

- Dit moet 'n reg wees wat in die lig van ומאת רות in Rut 4:5, ook aan Rut verbind kan word.

Vruggebruik is die reg op die opbrengs van 'n artikel wat aan iemand anders behoort. Vruggebruik is ' $n$ reg wat sedert die vroegste tye in die erfreg aangewend is om vir die weduwee ' $n$ wyse van oorlewing te vestig, en hierdie gebruik bestaan vandag nog. Deur die aandag te vestig op behoeftes wat eie is aan dié van die plaasbewoner, kan gepoog word om aan te toon hoedat soortgelyke omstandighede as die waarin die boek Rut hom afspeel, aanleiding kon gee tot 'n gebruik wat vandag nog in ons regstelsel van krag is. Dit word veral nog gesien in gevalle waar die egliede binne gemeenskap van goed getroud is, die eiendom 'n plaas of huis is, die omgewing landelik is, en die vrou nie opgelei is om ' $n$ ander werk te doen nie. Daarby word voorsien dat sy reeds bejaard kan wees wanneer haar man haar ontval. Die plaas vererf dan na die oudste seun, en 'n vruggebruik word ten gunste van die vrou oor die grond geregistreer. Omdat vruggebruik 'n persoonlike reg is, verval dit by die dood van die weduwee. Sy kan ook tydens haar leeftyd daarvan afstand doen deur dit te verkoop of te kanselleer, in welke geval die waarde van die blooteiendom sal verhoog.

'n Vruggebruik kan ook verhuur word teen vergoeding, dus ook ' $n$ manier waarop sy haar reg kan aanwend om 'n inkomste te verdien. Die vruggebruiker se reg bly voortbestaan, ongeag die verwisseling van eienaars van die grond. In hierdie geval sou dit dus nie saak maak of Naomi se seuns die grond geërf het, of iemand anders nie. Sou die grond "uit die boedel" van die laaste eienaar verkoop word (soos in hierdie geval aan die losser) sou haar status as vruggebruikster in elk geval onveranderd bly, en kan sy tydens dieselfde transaksie haar reg ook van die hand sit.

'n Interssante situasie doen hom hier voor. As Maglon (argumentsonthalwe Elimeleg se oudste seun en Rut se oorlede man) die grond van Elimeleg geërf het, onderhewig aan 'n beperkte reg wat ten gunste van Naomi uitgehou is, het Rut by Maglon se dood, as sy weduwee, dieselfde soort reg ten aansien van dieselfde stuk grond uitgehou. Die feit dat Naomi vir Rut as haar plaasvervanger aanbied, het dus nie net daarmee te doen dat sy te oud is om te trou nie. Rut is in dieselfde posisie as Naomi in verhouding tot die grond sowel as tot die losser, en kan sy dus gemaklik vir Naomi opvolg. Een en dieselfde reg kom albei vroue toe, en hulle sit dit gelyktydig van die hand. 
Omdat 'n vruggebruik 'n "beperkte reg" is, (dus iets minder as bloot eiendomsreg wat 'n omvattende reg is), maak die oorspronklike teks wat haar reg as 'n "aandeel" in die grond van haar oorlede man beskryf, dus volkome sin. In hierdie lig gesien, is dit dus onnodig om hierdie woord uit die vertaling uit weg te laat, en haar op onbegryplike wyse as die eienares van grond voor te stel.

As ons die verskynsel van vruggebruik op Rut 4:3 van toepassing kan maak, sal dit strook met wat Van den Brink (1995) te sê het oor die plig van kinders om vir hul weduweemoeder te sorg. Hy wys daarop dat daar eers in 1923 ' $n$ wet in Nederland uitgevaardig is waarkragtens 'n vrou in gelyke dele met haar kinders, van haar man kon erf. Hy noem dit egter 'n "uitholling" van die patriargale stelsel, wat altyd veronderstel het dat seuns die familiebesit erf, en hulle dan verplig is om vir hul moeder te sorg ... en dat “... aan de wettelijk erfopvolging (gericht op het byeenhouden van het familievermogen) niet getornd (moet) werden" (Van den Brink 1995:179) !

Hoewel die term "vruggebruik" nie in die Ou Testament voorkom nie, maak De Vaux (1962:60-61) wel daarvan melding. Sy bespreking van die term handel egter oor ' $n$ vader se hantering van sy dogter se bruidskat, en is die gesag wat hy aanhaal dus ongegrond en irrelevant.

Loader (1994a:80), is die enigste skrywer wat terloops die moontlikheid aanroer dat hier 'n vruggebruik ter sprake kan wees. Hy verstaan egter die begrip verkeerd, naamlik as "feitelijk beheer en alles wat daarmee saamhang." Derby (1994:1810) sien raak dat "... the childless widow is somehow indissolubly linked to the property ...", maar laat na om enige voorstel van wat hierdie skakel mag behels, aan die hand te doen.

1 Konings 8:6 bevestig myns insiens dat die gebruik bekend en algemeen aanvaar was, deurdat die opbrengs van die Sunamitiese weduwee se man se grond, wat waarskynlik na haar seun vererf het, ingesluit word by "alles wat aan haar behoort". Dit laat egter die vraag ontstaan of die afstand tussen twee ver verwyderde kulture met die verskynsel van "vruggebruik"oorbrug kan word. Van den Brink (1995:143-144) wys daarop dat Bybelvertalers graag hedendaagse terminologie volg. Die afwesigheid van 'n term in die antieke optekening, beteken nie dat die verskynsel nie bestaan het nie.

\section{7. 'N SOSIO-KULTURELE ONDERSOEK}

Venter (1983:11) bevestig dat die verhaal teen 'n sosio-kulturele agtergrond gelees moet word: "Maar omdat hierdie sosio-kulturele agtergrond so 
geweldig van die eietydse verskil, en histories so ver daarvan verwyder is, is verdere studie van hierdie aspek nodig".

Die optekening van mense se handelinge en die milieu waarteen dit afspeel, in ander tydvakke as dié waarin ons leef, gee aan ons die enigste toegang tot inligting oor hoe hulle geleef het. In hierdie geval het ons te doen met die antieke plaasroman. Gerleman (1965:7) noem dit 'n "familieroman". Die aandag word gevestig op behoeftes wat eie is aan dié van die plaasbewoner. Hierdie genre word dus die voertuig waarlangs gebruike wat vandag nog in ons regstelsel van krag is, herken word. Die basiese behoeftes van mense bly deur die eeue dieselfde. Oorlewing is die belangrikste hiervan, en die familieverband 'n sterk en veilige ruimte waarbinne dit verseker kan word. Voorbeelde uit die Ou Testament is legio. Die aanwending van hierdie tema, vind in die boek Rut 'n hoogtepunt. Die konsep van "vruggebruik" was deur die eeue heen 'n kragtige instrument wat oorlewing vir veral die weduwee gevestig het. Die feit dat die beginsel vandag nog bestaan, dui daarop dat die oorlewingsbehoefte steeds bestaan.

Bennet (1999:19) noem so 'n oorloop van behoeftes en gebruike oor geslagte en kulture heen, 'n "general evolutionary direction". Elliott (1993:36), laat toe dat ons 'n naam gee aan 'n konsep wat in die antieke tyd reeds bekend was, maar nog nie benoem is nie. Die ondersoeker mag voortgaan "(to) ... examine the ancient materials for evidence of such things- even though these concepts and terms are foreign to the language and conceptual world of the ancient natives and their writings" (Elliott 1993:40). Anders as wat verwag kan word, lê die oorbrugging wat hy aan die hand doen, nie in die histories-kritiese metode opgesluit nie, maar op die vlak van die Antropologie.

Ook Bennet (1999:9) bied 'n baie gemaklike verduideliking waarom die oorbrugging tussen kulture en tydvakke moontlik is. Hy verantwoord sy bewering wetenskaplik aan die hand van die werk gedoen deur sir Henry Maine (Ancient law 1861). Die grondslag van hierdie werk is ook antropologies van aard en dus weg van die moderne reg en die slaggat om antieke gegewe en kruiskulture vanuit 'n moderne oogpunt te lees: "By comparing various archaic legal systems ... he sought to discover a universal pattern of legal development. Implicit in this thesis, was the understanding that by comparison of disparate phenomena, a general evolutionary direction could be chartered ...."

Douglas (1992:ix) vind hierby aansluiting: "The Antropological project calls for a holistic view, over a long enough stretch of generations and over a large enough number of persons, for some pattern to appear". Douglas (1992:127), beklemtoon ook die familie as die prototipe van 'n sosiale 
kernmodel. Hieruit kan gebruike ontstaan, ontwikkel en gehandhaaf word, meestal om ekonomiese behoudsredes.

As aangetoon kan word dat die regsverskynsel waarmee ons in Rut 4:3 te doen het, soortgelyk is aan dit wat ons vandag ken as "vruggebruik", dan het hierdie gebruik die toets van die tyd deurstaan. Die ooreenkomste is reeds uitgewys.

\section{DIE FUNKSIE VAN DIE LITERÊRE ELEMENTE IN DIE BOEK RUT}

'n Ondersoek na die funksie van literêre elemente in die boek Rut, het gelei tot die hipotese in hierdie studie. Die funksie van die landelike milieu in die verhaal (wat deur bepaalde taalgebruik uitgebeeld word), kan in hierdie verband nie gering geskat word nie. Die narratiewe aanwending van die milieu en sekere herhaalde woorde, dui op 'n bepaalde konteks vir die aanwending van die gewoontereg, en skep die nodige atmosfeer daarvoor.

Een van die belangrikste begrippe is שדה (veld). Die woord "veld" of "velde" verskyn nie minder nie as 13 maal (waarvan 4 maal in hoofstuk 1) in die oorspronklike teks van die kort boek Rut. Die moontlikheid dat die woord 'n belangrike Leitmotif kan wees, kan dus nie misgekyk word nie. In verskillende vertalings van Rut 1:1 (vanaf veld, velde, landstreek, tot gebied), het hierdie stylfiguur egter sy trefkrag en belangrike funksie verloor. "Velde" is by uitstek dié atmosfeerskeppende woord, wat die speelveld gereed maak vir die aanwending van gebruike wat hul oorsprong in die plaaslewe gehad het. Beelde van wuiwende grasvelde word by die leser opgeroep onmiddellik na die opening van die eerste toneel (Rut 1:1). Die woord kondig 'n landelike opset aan en berei die leser voor op die leefwêreld wat hy besig is om te betree. Die kragtige instrument wat die status constructus bied, dra by om hierdie unieke gevoel te skep.

Pogings om aan te toon dat die meervoud hier 'n fout is ${ }^{9}$, en dat die enkelvoud van toepassing is omdat 'n stuk land in aardrykskundige sin (of dan "country"10) bedoel word, is onnodig. Die herhaling van in plaas van ארה in Rut 4:3, is veral opvallend. "Grond" of "land" word in die oorspronklike teks

\footnotetext{
${ }^{9}$ Morris (1968:245) haal Myers, Rudolph en ander aan, wat argumenteer dat dit nie 'n "genuine" meervoud is nie, maar die enkelvoud constructus van 'n argaïes-poëtiese vorm van שדה!

${ }^{10}$ Volgens Buhl (1949:779) in Handwörterbuch über das Alte Testament, kan שדה ook beteken "der allesumfassendes Land", of soos Reed (1962:266) in die IDB aandui: "A larger area than would be owned by one person".
} 
só geskryf dat dit lees"stukkie veld" ${ }^{11}$ Die funksie is tweërlei: dit is eerstens'n kunstige herhaling van 'n belangrike leitwort, en tweedens skep dit die indruk dat dit wat hier van die hand gesit word, 'n "mindere" of "beperkte reg" in eiendomsreg kan wees: 'n Vruggebruik?

\section{ENKELE AANSLUITENDE OPMERKINGS EN TEOLOGIE}

Gedagtig aan die tema van oorlewing, word die gebruik van "moederhuise" in Rut 1:8 ook betekenisvol. Daar is al verskeie verklarings vir die verwysing na "moederhuise" in plaas van "vaderhuise" soos verwag kan word, voorgestel. Die algemene gebruik in die heersende patriargale stelsel, was dat 'n meisie onder haar pa se beskerming in sy huis bly totdat haar man oorneem. (vgl De Vaux 1965:8). Die geval van Gomer, soos aangeteken in die boek Hosea, dui aan dat selfs 'n prostituut nie sonder hierdie beskerming was nie.

'n Enigsins feministiese verklaring, is dat die verwysing na "moederhuise" verband hou met die sterk rol wat vroue in die verhaal speel, of dat die stelsel wat in Moab geheers het, werklik 'n matriargale een was.

Loader (1994a:31), noem die moontlikheid dat Orpa en Rut se vaders ook reeds oorlede was. As dit die geval was, verklaar dit waarom die twee (kinderlose) meisies desperaat was vir 'n wyse van oorlewing, en dat Naomi hul enigste strooihalm was. Dit verklaar Rut se gedetermineerde optrede, en stel die egtheid van haar skeidingsverdriet onder verdenking. Die insluiting van dié gedeelte van haar beroemde troubelofte wat lui: "en daar begrawe word..." is onder meer 'n antieke eedsformule wat op 11 ander plekke in die Ou Testament voorkom ${ }^{12}$. Omdat die oorlewingstema so sterk in die verhaal figureer, is dit baie moontlik dat hier werklik verwys word na huise waar daar net 'n hulpbehoewende moeder oorgebly het. Die verwysing na (leë) moederhuise, is dus ook hoogs funksioneel tot die tema "leeg" en "vol". Dit dui op God se voorsienigheid. As Naomi terugkeer, word sy nie net vol nie, maar dit is ook 'n terugkeer na die wette, volk en verbond van God. Sy word ook saam met Sara en Hanna, die simbool van vrugbaarheid temidde van 'n andersins onomkeerbare onvrugbare toestand.

Die boek Rut kan dus simbolies wees vir die verbond van God, maar nie noodwendig omdat dit onwrikbare menslike trou tot die dood toe verbeeld

\footnotetext{
${ }^{11}$ Die King James Bible vertaal dit met "parcel of land". Die German Luther Bibel se vertaling met "den Anteil an dem Feld ...", is veral insiggewend.

121 Samuel 3:17, 14:44, 20:13, 25:22; 2 Sam 3:9 en 35, 19:13; 1 Kon 2:32, 19:2, 20:10; 2 Kon 6:37 (vgl in hierdie verband Prinsloo 1982:32-33). Vergelyk ook Morris (1968:261): Die betekenis van "begrawe" het beteken dat sy na haar dood by Naomi sou wees. Morris maak hier ook melding van die moontlikheid dat 'n sekere "houding" ingeneem is by die uitspreek van die formule, wat vergelyk kan word met 'n gebedshouding.
} 
nie. Die boek wil ook 'n herbevestiging wees van die beloftes van God, ongeag menslike besluite.

Was dit werklik Naomi se slim planne om te oorleef wat so goed gewerk het? Of was dit God se voorsienigheid om vir Rut met haar saam te stuur? Die oplossing was al daar nog voordat die krisis ontstaan het!

\section{Literatuurverwysings}

Alter, R 1981. The art of biblical narrative. New York: Basic Books.

Bennet, T W1988. The application of customary law in S.A. Johannesburg: Juta.

Bennet, T W 1999. A sourcebook of African customary law. Johannesburg: Juta.

Biale, R 1984. Women \& Jewish law. New York: Schocken Books.

Boecker, H J 1970. Redeformen des Rechtslebens im Alten Testament. Neukirchen-

Vluyn: Neukirchener Verlag.

Brueggeman, W 1979. The land. Philadelphia: Fortress.

Buhl, F 1949. Handwörterbuch über das Alte Testament, 779, in verband met "sadeh" Berlin: Springer Verlag.

Clasen, $F$ (red) 2000. Woordwyser: 'n Dag tot dag leesprogram vir 2001. Irene: Medpharm.

Derby, J 1990. The problem of the Levirate Marriage. Dor le Dor 17, 11-17. (The Jewish Bible Quarterly.)

Derby, J 1994. A problem in the book Ruth. Dor le Dor 22(3), 178-185. (Jewish Bible Quarterly.)

De Vaux, R 1962. Hoe het oude Israel leefde. Utrecht: J J Romen.

De Vos, W 1992. Regsgeskiedenis. Kaapstad: Juta.

Douglas, M 1992. Risk and blame: Essays in cultural theory. New York: Routledge.

Elliott, J H 1993. What is social-scientific criticism? Minneapolis, MN: Fortress.

Encyclopaedia Judaica, vol 12 \& 13, 1971.

Eskenazi, T C 1992. Out from the shadows: Biblical women in the postexilic era. Journal for the Study of the Old Testament 54, 25-42.

Gane, P 1955. The selective voet: Commentary on the pandectaes. Paris edition of 1829, vol 2 \& 7. Durban: Butterworths.

Gerleman, G 1965. Ruth. Neukirchen-Vluyn: Neukirchener Verlag. (Biblischer Kommentar 18.)

Haak, C 2002. Under his wings: The reformed witness hour. @www.prca.org/refwitness/2002/2002dec.01.html

Handsful of Purpose. 24/02/2004. Studies in Bible Doctrine, Track on line. @http://www.sibd,org/sibd/ruth/ruth_2.shtml (anoniem)

Human, D J 2003. Die Skrifvraagstuk en die Nuwe Hervorming. Verbum et Ecclesia, 24, 260-276.

Loader, J A 1994(a). Een praktische Bijbelverklaring: Text en Toelichting. Kampen: Kok.

Loader, J A 1994(b). David and the Matriarch in the book of Ruth. In die Skriflig 28, 25-35.

Matthews, V H \& Benjamin, D C 1995. Social world of ancient Israel 1250-587 BCE. Massachusettes, MA: Hendrickson. 
Morris, C L1968. Ruth: An introduction and commentary. Illinois, IL: Intervarsity Press.

"On the threshing floor of Boaz" 2004/02/24.

@ http://www.subd,irg/sibd/ruth/ruth_4.shtml (anoniem)

Patrick, D1986. Old Testament law. London: SCM.

Prinsloo, W S 1982. Die boek Rut. Kaapstad: NG Kerkuitgewers.

Reed, W L 1962. s v Field, Interpreter's Dictionary of the Bible, vol 2.

Van den Brink, H1995. Bijbels recht. Kampen: Kok.

Van der Merwe, F E 1989. Notariële praktyk. Pretoria: Digma.

Van Houten, C1991. The alien in Israelite law. Sheffield: JSOT Press.

Van Warmelo, P1965. ' $n$ Inleiding tot die studie van die Romeinse Reg. Kaapstad: Balkema.

Venter, P M 1983. Die Bybelboek Rut: 'n Bybelse Novelle. Intreerede, Universiteit van die Noorde, Pietersburg.

Venter, P M 1989. Die teenwoordigheid van God in die Rut-verhaal. HTS 45, $916-$ 932.

Vuilleumier, R 1988. Stellung und bedeutung des Buches Ruth in Alttestamentischen Kanon. Theologische Zeitschrift 44(3). Hrsg von K Seybold. Basel: F Reinhart Verlag.

Wiechers, N J, \& Vorster I 1984. Boedelbereddering. Durban: Butterworth. 